\title{
An empirical study to measure the impact of loan assignment for job creation and entrepreneurship programs
}

\author{
Gholamreza Taleghani $^{\mathrm{a}}$, Abolfazl Danaei ${ }^{\mathrm{b}}$ and Ramezan Fateminezhad $^{\mathrm{c}}$
}

${ }^{a}$ Associate professor, Department of Management, University of Tehran, Tehran, Iran

${ }^{b}$ Faculty member, Islamic Azad University of Semnan, Semnan, Iran

${ }^{c}$ IT senior expert, Treatment Management of Social Security Organization of Semnan Province, Semnan, Iran

AR T I C E I N F O AB S T R C T

Article history:

Received March 19, 2012

Received in Revised form

April, 25, 2012

Accepted 29 May 2012

Available online

June 22012

Keywords:

Entrepreneurship

Unemployment

Data Envelopment Analysis

\begin{abstract}
One of the primary concerns of many governmental agencies is to create job and working opportunities. The job creation is often promoted by loans devoted from the banks. This paper performs an empirical study to measure the relative efficiency of job creation from year 2002 to 2010 in different cities including Semnan, Dameghan, Shahrood, Garmsar and Mahdishahr located in west region of Iran. The proposed model of this paper uses data envelopment analysis where there are two inputs including the granted loans to private sector and the job applicants and two outputs including the assigned to work and the number of jobs created. The results indicate that the city of Garmsar represents the highest efficiency and Damghan maintains the lowest efficiency.
\end{abstract}

\section{Introduction}

During the past few decades, there has been an increasing trend on world's population and there is obviously an increase demand on creating new jobs. Entrepreneurship is among of the most effective methods for creating jobs based on new ideas (Parker, 2004; Nahid, 2010). Pfeiffer and Reize (2000) compared firm survival and employment growth of start-ups by unemployed and others, using the firm data from 15 regions in East and West Germany. They reported that self-selection impacts were taken into account by using simultaneous techniques of start-up promotion and firm development.

According to Stel et al. (2005) entrepreneurship is often considered to be a necessary aspect of the modern societies and therefore many people are interested in this concept and it is observed in the policy maker and academic communities. Many policy makers are also interested in promoting entrepreneurial ideas for boosting economic development, while academics are mostly concentrated in finding the underlying mechanism, which creates entrepreneurship links to development the theoretical infrastructures for the phenomenon. There are many studies in this area of work but still

\footnotetext{
* Corresponding author. Tel: +989121316312

E-mail addresses: danaei11@yahoo.com (A. Danaei) 
there is a need to know the causes of the entrepreneurship and its consequences for the development due to conceptual and methodological limitations. Both, entrepreneurship and development are complex concepts and difficult for measuring and their concepts may be different in meaning according to the various theoretical concepts. According to Reynolds et al. $(1994,1995)$ many people argue that the entrepreneurship and development is a more complex phenomena, which is not only conditioned by cultural elements, but also by political, institutional and individual factors.

Nickell et al. (1996; 1997) performed an investigation on the role of three external factors in creating improved productivity performance in companies. These are product market competition, financial market pressure and shareholder control. They used data from around $580 \mathrm{UK}$ manufacturing companies mostly associated with some degree of increased productivity growth. More specifically, average rents normalized on value-added were negatively associated with productivity growth, interest payments normalized on cash flow were positively associated with future productivity growth and firms with a dominant external shareholder from the financial sector had higher productivity growth rates. Geroski (1989) performed and empirical study to measure the impact of innovation on increasing productivity.

Highfield and Smiley (1987) detected two main factors, which impact the rate of creation of new firms; macroeconomic and microeconomic. The macroeconomic climate that happens to be most conducive to the formation of small businesses is also called sluggish. Lower rates of growth of GNP, lower inflation rates, and greater growth in the unemployment rate were followed by elevations in the rate of new firms. They do not detect any of the traditional barriers to entry to be associated with the rate of new firm creation.

Hamilton (1987) explained that time-series analyses generally demonstrate rates of business formation increasing with unemployment. In cross-section investigations, the areas with the highest rates of formation are generally those with the lowest levels of unemployment. In his study, the negative cross-section relationship is confirmed but it was recommended that the time-series could be nonlinear, becoming negative at a critical unemployment level around $20 \%$.

Grilo and Thurik (2005) used a multinomial logit model and surveyed data from the 25 EU member states and the US to build the effect of demographic and other variables on various entrepreneurial engagement levels. These engagement levels were varied from "never thought about starting a business" to "thinking about it", "taking steps for starting up", "having a young business", "having an older business" and "no longer being an entrepreneur". According to their study, among the four perception variables only administrative complexities displayed an unambiguous obstacle profile because its presence had a significant negative influence on higher entrepreneurial engagement levels.

Grilo and Thurik (2006) presented new insights on the determinants of entrepreneurial attitudes and activities by examining the relationship between institutional variables and cross-country changes in the preferences for self-employment as well as in actual self-employment. They gathered data of the 25 member states of the European Union as well as the US and found that country specific variables seemed to explain the preference for entrepreneurship but not the actual entrepreneurship.

According to Acs et al. (2003) contemporary theories of entrepreneurship normally concentrate on the decision-making context of the individual and the recognition of chances and the decision to commercialize them is the focal concern. The opportunities are normally exogenous, the most prevalent theory of innovation in the economics literature recommends that opportunities are endogenous. Acs et al. (2003) tried to bridges the gap between the entrepreneurship and economic literature on opportunity by proposing a knowledge spillover theory of entrepreneurship. Their results indicated that there was a strong relationship between knowledge spillovers and new venture creation. 
In this paper, we present an empirical investigation to study the effects of loans dedicated for entrepreneur to create jobs and working opportunities in different cities located in province of Semnan, Iran.

We first provide some details of the numbers of figures associated with the proposed model in section 2. Section 3 is devoted for the methodology and the results of our study are given in section 4 . The paper concludes the results in section 5 to summarize the contribution of the paper.

\section{The relationship between unemployment and entrepreneurship}

In this study, we first gathered the number of licenses issued by the government of Iran in different cities. Next we examine the impact of this factor on creating job opportunities. Table 1 shows details of the number of permits issued, the number of people who were employed and the number of unemployed people.

Table 1

The Statistical Information of the Semnan province in the years 2002-2010

\begin{tabular}{lllllll}
\hline & \multicolumn{2}{l}{ Employed population } & \multicolumn{2}{l}{ Unemployed Population } & \multicolumn{2}{c}{ The amount of permits issued } \\
\hline Year & Number & Normalized & Number & Normalized & Normalized & Number \\
\hline 2002 & - & - & - & - & 1802 & 0.237 \\
2006 & 33247 & 0.089 & 0.039 & 1181 & 1305 & 0.172 \\
2007 & 58401 & 0.156 & 0.243 & 7344 & 1515 & 0.199 \\
2008 & 69424 & 0.185 & 0.186 & 5632 & 1619 & 0.213 \\
2009 & 85618 & 0.228 & 0.132 & 3996 & 858 & 0.113 \\
2010 & 128638 & 0.342 & 0.40 & 12095 & 502 & 0.066 \\
\hline Total & 375328 & 1 & 1 & 30248 & 7601 & 1 \\
\hline
\end{tabular}

\section{The Data Envelopment Analysis}

Data envelopment analysis (DEA) is one of the most efficient and popular method for measuring the relative efficiencies of different similar units where there are more than one inputs and outputs associated with decision units. Let $x_{i j}$ be the inputs for a decision unit with $i=1, \ldots, m$ and $y_{r j}$ be the outputs with $r=1, \ldots, s$ and $j=1, \ldots, n$. Let $u_{i}$ and $v_{j}$ be the dual variables associated with $x_{i}$ and $y_{j}$, respectively. The constant to scale DEA model is formulated as follows,

$\max$

$$
Z=\frac{\sum_{r=1}^{s} u_{r} y_{r .}}{\sum_{i=1}^{m} v_{i} x_{i}}
$$

subject to $\frac{\sum_{r=1}^{s} u_{r} y_{r j}}{\sum_{i=1}^{m} v_{i} x_{i j}} \leq 1$.

$$
u_{r}, v_{i} \geq 0, \quad j=1, \ldots, n
$$

Model (1) is the basis of traditional DEA and it is solved $j$ times to determine the relative efficiencies of various units. However, since (1) is nonlinear in structure, Charles et al. (1983) suggest a simple modification of the objective function to simplify the structure of the resulted problem as follows, 
$\max$

$$
Z=\sum_{r=1}^{s} u_{r} y_{r}
$$

$$
\begin{array}{ll}
\text { subject to } & \frac{\sum_{r=1}^{s} u_{r} y_{r j}}{\sum_{i=1}^{m} v_{i} x_{i j}} \leq 1 . \\
& \sum_{i=1}^{m} v_{i} x_{i .}=1 \\
& u_{r}, v_{i} \geq 0, \quad j=1, \ldots, n
\end{array}
$$

Note that the first constraint also becomes linear using a simple manipulation. Problem (2) has been widely used for the past three decades and the results are commonly accepted as a tool to measure the relative efficiency of different units. However, when there is uncertainty with the inputs and the outputs, one may use different techniques to make sure that a small change on input/output data does not change the output rankings.

\section{The research methodology}

The proposed model of this paper uses two inputs (job applications and granted loans) and two outputs (assigned to work and number of jobs created). The data are gathered from five different cities of Semnan province including Semnan, Dameghan, Shahrood, Garmsar and Mahdishahr. Fig. 1 shows details of our proposed study.

Inputs

Outputs

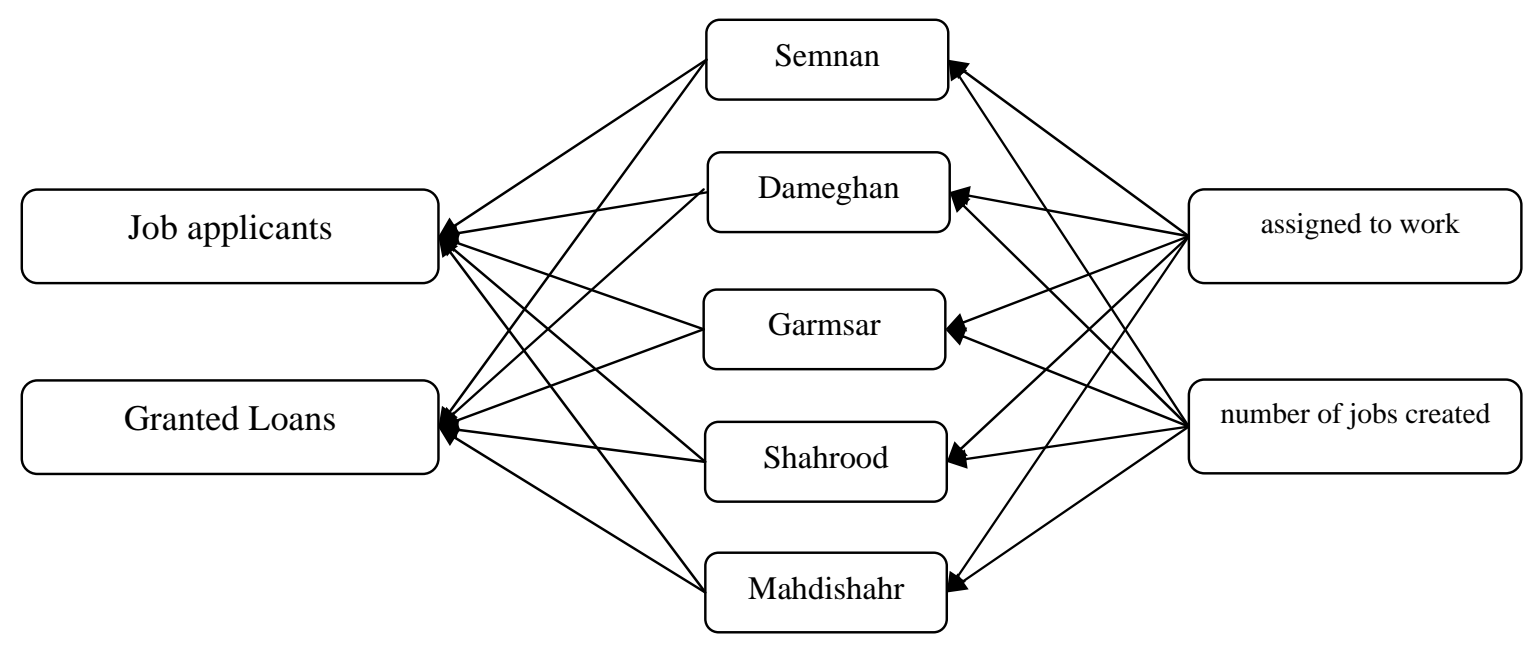

Fig. 1 The Conceptual model

Table 2 demonstrates the numbers gathered for inputs and outputs of the proposed model of this paper. As we can observe, there was relatively huge amount of loan dedicated to city of Garmsar 
during the fiscal year of 2009. However, the other cities could manage to create almost the same figures without receiving such amount of loans.

\section{Table 2}

The Statistical information (Inputs and outputs) for Semnan to the province Separation (Currency: Billion rials, Year: 2010)

\begin{tabular}{lcccc}
\hline DMU & $\begin{array}{c}\text { The Granted Loans to } \\
\text { Private }\end{array}$ & $\begin{array}{c}\mathrm{I}_{2} \\
\text { The Job } \\
\text { applicants }\end{array}$ & $\begin{array}{c}\mathrm{O}_{1} \\
\text { The assigned to } \\
\text { work }\end{array}$ & $\begin{array}{c}\text { The number of jobs } \\
\text { created }\end{array}$ \\
\hline Semnan & 24303 & 10534 & 3672 & 4992 \\
\hline Dameghan & 16961 & 1463 & 741 & 741 \\
\hline Shahrood & 2310 & 5389 & 2838 & 2832 \\
\hline Garmsar & 417915 & 4475 & 2932 & 7169 \\
\hline Mahdishahr & 5081 & 1542 & 753 & 793 \\
\hline Source: The Department of Labor and Social Affairs of Semnan, Semnan Bank
\end{tabular}

That after formulating the information in table 2 in CCR model of Data Envelopment Analysis and solving it by GAMS software, the following results will be achieved:

Table 3

The ranking of the Semnan cities in terms of performance in entrepreneurial activities

\begin{tabular}{llllll}
\hline city & Semnan & Dameghan & Shahrood & Garmsar & Mahdishahr \\
\hline Efficiency (\%) & 82.269 & 77.304 & 80.377 & 100 & 90.552 \\
\hline Degree & 3 & 5 & 4 & 1 & 2 \\
\hline
\end{tabular}

According to the information above Garmsar city with performance score of $100 \%$ was introduced as the First of degree and the most efficient city in entrepreneurial activities and Dameghan city with performance score of $77.304 \%$ as the fifth rank and the most deficient. Also the acceptable amount (the goal) for the outputs of the inefficient units in the present conditions (Without changing the input) are as follows:

Table 4

A sensitivity analysis on the efficieny of different units

\begin{tabular}{llllll}
\hline Cities & Semnan & Dameghan & Shahrood & Garmsar & Mahdishahr \\
\hline The assigned to work in 2010 & From 3672 to 4619 & Fixed & Fixed & Fixed & Fixed \\
\hline The number of jobs created & Fixed & From 741 to 801 & From 2832 to 30671 & Fixed & From 793 to 814 \\
\hline
\end{tabular}

\section{Conclusion}

In this paper, we have presented an empirical study to measure the effects of governmental facilities provided for entrepreneurs to create job opportunities for a period of six years started from 2002 to 2010. The proposed model has adapted data envelopment analysis to measure the relative efficiencies of loan assignments in five main cities located in province of Semnan, Iran. The proposed model used two inputs namely the amount of loans and the number of people who filled for job opportunities. The outputs of the model were the number of jobs, which were actually created and the assigned work. The results of our study indicate governments opportunities do not necessarily have the same impact in different places and job creations also need other infrastructures.

\section{Acknowledgment}

The authors would like to thank the people and officials who helped us gather the necessary data. We are also grateful to anonymous referees' insights on earlier version of this paper. 


\section{Reference}

Acs, Z., Audretsch, D., Braunerhjelm, P., \& Carlsson, B. (2003). The missing link: The knowledge filter. Entrepreneurship and Endogenous Growth, Working Paper, Center for Economic Policy Research, Stockholm.

Charnes, A., Cooper, W.W., Rhodes, E. (1978). Measuring the efficiency of decision making units. European Journal of Operational Research, 2, 429-444.

Geroski, P. (1989). Entry, innovation, and productivity growth. Review of Economics and Statistics, 71, 572-578.

Grilo, I., \& Irigoyen, J.M. (2006). Entrepreneurship in the EU: to wish and not to be. Small Business Economics, 26(4), 305-318.

Grilo, I., \& Thurik, R. (2005). Entrepreneurial engagement levels in the European union. International Journal of Entrepreneurship Education, 3(2), 143-168.

Hamilton, R. (1989), Unemployment and business formation rates: Reconciling time series and cross section evidence. Environment and Planning, 21, 249-255.

Highfield, R., \& Smiley, R. (1987). New business starts and economic activity: An empirical investigation. International Journal of Industrial Organization, 5, 51-66.

Nahid, M. (2010). Nature and reason of entrepreneurship and organizational entrepreneurship in one glance. Commercial Survey Publication, 34, 39-58. [In Persian].

Nickell, S. (1996). Competition and corporate performance. Journal of Political Economy 104, 724746.

Nickell, S., Nicolitsas, N., \& Dryden, N. (1997). What Makes Firms Perform Well?, European Economic Review, 41, 783-796.

Oxenfeldt, A. (1943). New Firms and Free Enterprise. Washington, D.C. American Council on Public Affairs.

Parker, S. (2004). The Economics of Self-Employment and Entrepreneurship. Cambridge, UK: Cambridge University Press.

Pfeiffer, F., \& Reize, F. (2000). Business start-ups by the unemployed an econometric analysis based on firm data. Labour Economics, 7 (5), 629-663.

Reynolds, P., Miller, B., \& Maki, W. (1995). Explaining regional variation in business births and deaths: U.S. 1976-1988. Small Business Economics, 7(5), 389-707.

Reynolds, P., Storey, D., \& West Head, P. (1994), Cross-national comparisons of the variation in new firm formation rates. Regional Studies, 28(4), 443-456.

Stel, A., Carree, M., \& Thurik, R. (2005). The effect of entrepreneurial activity on national economic growth. Small Business Economics, 24 (3), 311-321. 